\title{
Emotional Intelligence and Leadership Style As Determining Factors of Individual Employee Competencies
}

Andi Ririn Oktaviani, Muhammad Ismail P \& Arifin

\section{ABSTRACT}

High employee competencies are expected to support the achievement of the company's success. Achieving the competence of each individual employee is influenced by several factors, including emotional intelligence and leadership styles that apply in the company. This study aims to examine emotional intelligence and leadership style as one of the determinants of achieving individual competencies of employees of state-owned cement companies in Indonesia. The results of the study showed that the state-owned cement company employees had high emotional intelligence which had an impact on the development and improvement of their competencies. While the tendency of the prevailing leadership style is transformational leadership style.

Keywords: emotional intelligence, leadership style, employee competence.

Classification: JEL Code: M19

Language: English

London 


\title{
Emotional Intelligence and Leadership Style As Determining Factors of Individual Employee Competencies
}

\author{
Andi Ririn Oktaviani ${ }^{\alpha}$, Muhammad Ismail $\mathrm{P}^{\sigma}$ \& Arifin $^{\circ}$
}

\begin{abstract}
High employee competencies are expected to support the achievement of the company's success. Achieving the competence of each individual employee is influenced by several factors, including emotional intelligence and leadership styles that apply in the company. This study aims to examine emotional intelligence and leadership style as one of the determinants of achieving individual competencies of employees of state-owned cement companies in Indonesia. The results of the study showed that the state-owned cement company employees had high emotional intelligence which had an impact on the development and improvement of their competencies. While the tendency of the prevailing leadership style is transformational leadership style.
\end{abstract}

Keywords: emotional intelligence, leadership style, employee competence.

\section{INTRODUCTION}

Research on intelligence as a determinant of the success of each individual employee raises a variety of theories and differences of opinion regarding what intelligence factors can predominantly encourage increased competence and success of individual work. The study of the dimensions of popular intelligence was proposed by Daniel Goleman with the idea that the greatest emotional intelligence contributes to the achievement of one's success so that it can enable them to develop competencies both individually and in groups in the work team compared to other elements of intelligence.
In addition to intelligence factors, some experts argue that leadership style is also the most important factor in encouraging individual employees to develop their competencies. This assumption tends to view leadership style as a series of personal qualities that are clearly defined (such as vision, characteristics, intelligence, tenacity, etc.) which are only owned by a few people and can have an effect on subordinates trying to develop competencies as required by the company. There are various different leadership styles in state-owned cement companies. In this approach, the main focus shifts from identifying a set of universal leadership competencies to identifying a number of alternative leadership styles. In other words, the behavioral approach seeks to determine that what leaders do is effective, for example, how they delegate tasks, communicate and motivate subordinates and so on. The behavioral approach is focused on two aspects of leadership behavior, namely leadership functions (task-related functions and group maintenance) and leadership style (task-related and group maintenance).

\section{THEORITICAL REVIEW}

\subsection{Emotional Intelligence Concept}

Individually intelligence plays an important role in developing the work ability of employees. This is in line with some of the results of research conducted by (Trihandini, 2005), (Rahmasari, 2012), (Trihandini, 2013), (Setiawan, 2016), (Widana, 2017). Emotional intelligence has become increasingly popular as a measure to identify potentially effective leaders, and as a tool for developing effective leadership skills. There are several empirical studies that justify the 
dominant role of emotional intelligence in these fields. Emotional intelligence correlates with several components of transformational leadership that show that it may be an important component of effective leadership. Specifically emotional intelligence can explain how leaders effectively monitor and respond to subordinates and make them feel they are working (Palmer et al., 2001).The emotional and managerial intelligence models developed were used to identify manager's leadership styles (Barling, Slater and Kelloway, 200o), (Ogbonna and Harris, 2000), (McColl-Kennedy and Anderson, 2002), (Eagly and Carli, 2003), ( Eagly, Johannesen-Schmidt and Van Engen, 2003), (Mohammad Mosadegh Rad and Hossein Yarmohammadian, 2006), (Müller and Turner, 2007), (Timothy et al., 2011).

\subsection{Leadership Style Concept}

Academic literature strongly supports the view that leadership quality is mostly present to those who have competency qualifications and expected performance expectations. Leadership style generally influences subordinates to carry out work and fulfill the competencies and performance required by the company (Spector, 1988), (Howell and Avolio, 1993), (Wang, Bowling and Eschleman, 2010), (April, Dharani and Peters, 2012).

Some experts argue that the concept of leadership style must be understood not as a series of individual qualities but as a relational phenomenon. Leaders are there if there are followers and leaders can only be good leaders if their actions are in line with stereotypical perceptions of other parties regarding good leadership style and this means that someone can lose his status as a leader if he is abandoned by his followers. Based on this perspective, it should be understood not only leadership style but also followership (why and in what situations are people willing to be led). In addition, there is also a group of experts, especially postmodernists, who argue that leadership style is more of a state of mind than an objective reality. The process of identifying someone as an effective leader is only valid for or after he shows certain behaviors that are perceived as "leader like behaviors". His status as a leader must be constantly reproduced and strengthened because if a leader fails, his failure is not because his performance has faded but because his followers interpretation his actions are no longer in line with their ideal expectations (Müller and Turner, 2010), (Caliendo, Cobb-Clark and Uhlendorff, 2015).

Effective leadership is very important for organizations that are changing rapidly now. Emotional intelligence has been identified by several people as an important element needed for effective leadership. Although research is developing, there is still a gap in the relationship that exists between emotional intelligence and leadership. Some previous studies have shown that the best leaders do not depend only on one leadership style. The six styles are coercive, authoritative, affiliative, democratic, speed determinant and coaching. The more style shown by a leader, the better (Goleman, 2000).

\subsection{Competence Concept}

Character and behavior or willingness and ability to master themselves and understand the environment objectively and morally, because of the relatively stable emotional patterns when facing various pressures of problems in the workplace, which are formed from the synergy between character, self-concept, internal motivation, and mental capacity/emotional. The development of competency models does not only refer to the overly simplistic views related to the effectiveness of leadership styles, but the overall synergy of more comprehensive factors such as emotional intelligence (Eagly and Johnson, 1990), (Edum-Fotwe and McCaffer, 2000), (R., Gosling, J., Marturano, A. and Dennison et al., 2003), (Hollenbeck, McCall and Silzer, 2006), (Carroll, Levy and Richmond, 2008). Some previous studies have tried to explore the relationship between emotional intelligence, leadership style, and employee competency achievement (Rotemberg and Saloner, 1993), (Turner and 
Müller, 2005), (Weinberger, 2009), (Saeed et al., 2014).

It is interesting to examine how employees in the company related to their organization in the required standard work arrangements. However, little is understood about how leadership style behavior influences employee competency. Without leadership, employees find it difficult to identify work goals and objectives (Solansky, 2008), (Dahlstrom, 2013). Three aspects of transformational leadership (i.e. ideal influence, inspirational motivation, and individual considerations) different according to the level of emotional intelligence. Conversely, there is no multivariate effect that appears for transactional leadership (Barling, Slater and Kelloway, 2000). Effective leadership style increases work engagement and employee competency (Tims, Bakker and Xanthopoulou, 2011).

Higher social support perceptions, greater effectiveness beliefs, lower negative influences, and lower threat assessments are causal models which mean that leadership styles have a direct effect on the development and improvement of employee competencies (Park, 1996 ), (Lyons and
Schneider, 2009), (Abernethy, Bouwens and van Lent, 2010), (Yang, Huang and $\mathrm{Wu}, 2011$ ). Transformational and transactional leadership becomes the most efficient influence between leadership styles in achieving employee work competencies (Kerr and Jermier, 1978), (Blake and Mouton, 1982), (Westley and Mintzberg, 1989), (Tierney, Farmer and Graen, 1999), (Berson et al., 2001), (Jung, Chow and Wu, 2003), (Van Vugt et al., 2004), (Chen and Silverthorne, 2005), (Dulewicz and Higgs, 2005), (de Vries, Bakker-Pieper and Oostenveld, 2010), (Bucic, Robinson and Ramburuth, 2010), (Oreg and Berson, 2011), (Ahmad et al., 2013), (Zulch, 2014), (Anderson and Sun, 2017).

\section{RESEARCH METHODOLOGY}

This research has been conducted at PT Semen Indonesia, PT Semen Padang, PT Semen Gresik and PT Semen Tonasa. There were 339 respondents selected as samples using random sampling. Questionnaires and interviews are used as tools in data collection methods. The data analysis technique in this study is structural equation model (SEM).

\section{FINDINGS}

Table 4.1: Description of Variable Emotional Intelligence (X1)

\begin{tabular}{|c|c|c|c|c|c|c|c|c|c|c|c|}
\hline \multirow{3}{*}{ Indicator } & \multicolumn{10}{|c|}{ Respondent's Response } & \multirow{3}{*}{ Mean } \\
\hline & \multicolumn{2}{|c|}{1} & \multicolumn{2}{|c|}{2} & \multicolumn{2}{|c|}{3} & \multicolumn{2}{|c|}{4} & \multicolumn{2}{|c|}{5} & \\
\hline & $\mathrm{F}$ & $\%$ & $\mathrm{~F}$ & $\%$ & $\mathrm{~F}$ & $\%$ & $\mathrm{~F}$ & $\%$ & $\mathrm{~F}$ & $\%$ & \\
\hline Self-awareness & - & - & - & - & 9 & 2,7 & 215 & 63,4 & 115 & 33,9 & 4,31 \\
\hline Self-regulation & - & - & - & - & 13 & 3,8 & 204 & 60,2 & 122 & 36,0 & 4,32 \\
\hline Self-motivation & - & - & - & - & 18 & 5,3 & 226 & 66,7 & 95 & 28,0 & 4,23 \\
\hline Empathy & - & - & - & - & 45 & 13,3 & 224 & 66,1 & 70 & 20,6 & 4,07 \\
\hline Social skills & - & - & - & - & 25 & 7,4 & 239 & 70,5 & 75 & 22,1 & 4,15 \\
\hline & & & & & & & & & & & 4.22 \\
\hline
\end{tabular}


Emotional intelligence of state-owned cement company employees is an embodiment of the character attitude and behavior or willingness and ability to master themselves and understand the environment objectively and morally because of emotional patterns that are relatively stable when facing various stress problems in the workplace formed from synergy between character, self-concept, internal motivation, and mental/emotional capacity. The emotional capacity of employees in this study is internalized in the form of indicators of self-awareness, self-regulation, self-motivation, empathy, and social skills (indicators refer to views (Goleman, 2000). Empirical findings indicate that each question from each indicator of emotional intelligence in research is in accordance with employee competencies.

Emotional intelligence means that an employee has the ability to know their strengths and weaknesses, be able to handle emotions themselves, be able to motivate themselves to move forward, be able to feel the emotions and personality of other people able to establish relationships with others. Statistical results from the dimensions of emotional intelligence in this study indicate the mean value of each question based on each indicator of 4.22. This proves that employees in state-owned cement companies have high emotional intelligence, where each individual employee naturally longs for a calm and healthy life both physically and spiritually.

Each employee is susceptible to various problems and obstacles that occur in the family and coworkers and companies so that they have the potential to experience anxiety,dissatisfaction and excessive emotions. Generally the more successful an employee is, the more life complications they experience. Competition, and opposition due to needs and desires that must be fulfilled make it difficult for an employee to get a healthy mentality. Therefore, emotional intelligence is very important for every employee in a state-owned cement company in Indonesia.

Table 4.2: Description of Leadership Style Variables (X2)

\begin{tabular}{|c|c|c|c|c|c|c|c|c|c|c|c|}
\hline \multirow{3}{*}{ Indicator } & \multicolumn{10}{|c|}{ Respondent's Response } & \multirow{3}{*}{ Mean } \\
\hline & \multicolumn{2}{|c|}{1} & \multicolumn{2}{|c|}{2} & \multicolumn{2}{|c|}{3} & \multicolumn{2}{|c|}{4} & \multicolumn{2}{|c|}{5} & \\
\hline & $\mathrm{F}$ & $\%$ & $\mathrm{~F}$ & $\%$ & $\mathrm{~F}$ & $\%$ & $\mathrm{~F}$ & $\%$ & $\mathrm{~F}$ & $\%$ & \\
\hline $\begin{array}{l}\text { The ability of subordinates is } \\
\text { doubtful }\end{array}$ & 1 & 0,3 & 25 & 7,4 & 86 & 25,4 & 179 & 52,8 & 48 & 14,2 & 3,73 \\
\hline $\begin{array}{l}\text { Leaders give absolute freedom } \\
\text { to subordinates }\end{array}$ & - & - & 3 & 0,9 & 107 & 31,6 & 202 & 59,6 & 27 & 8,0 & 3,75 \\
\hline $\begin{array}{l}\text { Leaders are responsive to the } \\
\text { interests of subordinates }\end{array}$ & 1 & 0,3 & 24 & 7,1 & 114 & 33,6 & 154 & 45,4 & 46 & 13,6 & 3,65 \\
\hline $\begin{array}{l}\text { Leaders encourage } \\
\text { subordinates to achieve targets } \\
\text { and prioritize group interests }\end{array}$ & - & - & 2 & 0,6 & 67 & 19,8 & 228 & 67,3 & 42 & 12,4 & 3,91 \\
\hline $\begin{array}{l}\text { Leaders consistently fulfill the } \\
\text { mission and realize the } \\
\text { strengths and weaknesses of } \\
\text { personal and organizational self }\end{array}$ & 1 & 0,3 & 6 & 1,8 & 92 & 27,1 & 197 & 58,1 & 43 & 12,7 & 3,81 \\
\hline $\begin{array}{l}\text { The leader has a firm nature, } \\
\text { fast, and gives direction } \\
\text { according to the situation that } \\
\text { occurs }\end{array}$ & - & - & 3 & 0,9 & 75 & 22,1 & 219 & 64,6 & 42 & 12,4 & 3,88 \\
\hline & & & & & & & & & & & 3,79 \\
\hline
\end{tabular}

Source: Data processed (2018) 
Effective leadership style is only possible to achieve organizational goals productively. The leadership style influences the competence and productivity of employees of state-owned cement companies. There are six forms of leadership style applied in state-owned cement companies and the majority are transformational leadership styles. Some of the literature on previous leadership styles that influence employee work competency achievement illustrates that the effectiveness of leadership styles has many forms. The impact on competence can be important and cannot be separated from intelligence factors (Bennis and Thomas, 2002), (Nanjundeswaraswamy and Swamy, 2014).

Autocratic leadership style, 179 respondents choose the agreed answer can be interpreted employees in state-owned cement companies on average have a perception that the work will be effectively carried out if each employee follows the same procedures and routine responsibilities every day. This is influenced by the availability of complete company documents to carry out the analysis needs of the organizational structure such as job description and job grade in each work unit so that individual employees clearly know the position and responsibility of work in their respective work units. Leaders with the tendency of autocratic leadership styles relevant to the trait theory proposed by (Gordon Willard Allport, 1967) that a leader has a person and character that is different from others. A far-sighted, creative and innovative leader, has a dominating desire, is confident in his own abilities, and is able to assume responsibility. This can be positive if the leadership with a leadership style tends to be autocratic able to encourage the achievement of competencies and performance of employees in state-owned cement companies.

Laissez faire leadership style, employees choose answers agree as many as 202 people can be interpreted that employees in state-owned cement companies believe that the leadership is sufficient to provide concessions to employees in developing work methods that are considered effective to achieve expected work performance and confidence that involvement and the contribution of each employee is important in formulating policies and decision making.

Transactional leadership style, respondents gave a response agreed as many as 154 people described that most employees think the leader knows what is expected by subordinates and is able to provide confidence that each employee will get what they expect if their performance meets expectations. On average, it can be interpreted that each individual employee in a state-owned cement company realizes that by meeting competency and performance requirements as required by the company, it will produce good feedback on their career and work. This is in line with transactional theory proposed by James McGregor and Burns (1978), who argue that a leader must be sensitive to the desires or demands of subordinates and responsive to the success and failures of subordinates.

Transformational leadership style, as many as 228 people argued that the majority of employees trust and respect the leadership for their integrity so that employees are motivated to improve core competencies, leadership competencies, and technical competencies required by the company. Leaders are considered to have the ability to inspire positive changes to their subordinates. This is also in line with the opinion (Burn \& Bass, 1985) which states that good leaders are able to motivate their subordinates to achieve the company's goals and targets.

Charismatic leadership style, as many as 197 people believe that leaders with a tendency towards charismatic leadership styles are able to convince their employees to follow their direction and emotionally believe in the integrity of the leadership so that employees want to contribute in achieving company goals. Although there are several leadership level employees who are in echelon 1 and 2 young people based on respondents' characteristic data, the average respondent choose an agreed answer that can be interpreted that the criteria for being a charismatic leader is not based on age, wealth, 
profile or health but charisma and confidence that is displayed so that it can influence and direct subordinates.

Situational leadership style, as many as 219 employees have the perception that generally employees in state-owned cement companies believe that the leadership is able to adjust the developmental stages of competency and performance of each employee in the process of carrying out the work. Related to this, research (Ralph Stogdill, 1904-1947) describes several key components of the situation in the scope of work, namely mental maturity, status, expertise, needs, subordinates, and objectives to be achieved.

Table 4.3: Description of Competency Variables (Y)

\begin{tabular}{|c|c|c|c|c|c|c|c|c|c|c|c|}
\hline \multirow{2}{*}{ Indicator } & \multicolumn{7}{|c|}{ Respondent's Response } & \multicolumn{2}{c|}{ Mean } \\
\cline { 2 - 14 } & \multicolumn{2}{|c|}{1} & \multicolumn{2}{|c|}{2} & \multicolumn{2}{|c|}{3} & \multicolumn{2}{|c|}{4} & \multicolumn{2}{|c|}{5} & \\
\cline { 2 - 13 } & $\mathrm{F}$ & $\%$ & $\mathrm{~F}$ & $\%$ & $\mathrm{~F}$ & $\%$ & $\mathrm{~F}$ & $\%$ & $\mathrm{~F}$ & $\%$ & \\
\hline Character & - & - & - & - & 18 & 5,3 & 250 & 73,7 & 71 & 20,9 & 4,16 \\
\hline Motive & - & - & - & - & 33 & 9,7 & 239 & 70,5 & 67 & 19,8 & 4,10 \\
\hline Nature & - & - & - & - & 42 & 12,4 & 272 & 80,2 & 25 & 7,4 & 3,95 \\
\hline Knowledge & - & - & 1 & 0,3 & 44 & 13,0 & 252 & 74,3 & 42 & 12,4 & 3,99 \\
\hline Skills/expertise & - & - & - & - & 27 & 8,0 & 238 & 70,2 & 74 & 21,8 & 4,14 \\
\hline
\end{tabular}

Source: Data processed (2018)

The competencies required in state-owned cement companies that are the object of this research consist of core competencies, leadership competencies and technical competencies. Core competencies are required for all employees in the company based on the competency framework that applies to every employee in the company even though at different levels, for example each individual employee is required to have self-integrity and be able to cooperate.

The next competency that the company requires is leadership competencies related to individual leadership characteristics that can affect its subordinates. Competencies at the top leadership for example result/achievement orientation, relationship building, initiative, strategic thinking, building organizational commitment, and developing others. Middle-level competency focuses more on influence, team work, analitycal thinking, conceptual thinking, relationship building, service orientation, and technical expertise. While supervisory level competencies focus more on interpersonal understanding, concern for order, influence, flexibility, team work, and cross cultural sensitivity.

The third important competency fulfilled by employees in state-owned cement companies is technical competence related to specific tasks for each individual or group of employees in each work unit. The leader assesses technical competencies based on the behavioral indicators raised by the employee, then matches the behavioral indicators in the dictionary of company competencies starting from the level that is the requirement in the position then the assessment can move to a higher or lower level. For example employees in the logistics work unit with inventory management qualifications, procurement management, and warehouse. While the technical competencies commonly possessed by employees in the company are management concern for quality and order, and holding people accountable. 


\section{CONCLUSION}

1. Employees of state-owned cement companies have on average, high emotional intelligence that enables them to develop and improve work competencies to meet the competencies required by the company.

2. On average, transformational leadership styles are applied in state-owned cement companies.

\section{REFERENCE}

1. Abernethy, M. A., Bouwens, J. and van Lent, L. (2010) 'Leadership and control system design', Management Accounting Research. doi: 10.1016/j.mar.2009.10.002.

2. Ahmad, A. R. et al. (2013) 'The influence of leadership style on job satisfaction among nurses', Asian Social Science. doi: 10.5539/ass.v9n9p172.

3. Anderson, M. H. and Sun, P. Y. T. (2017) 'Reviewing Leadership Styles: Overlaps and the Need for a New "Full-Range" Theory', International Journal of Management Reviews. doi: 10.1111/ijmr.12082.

4. April, K. A., Dharani, B. and Peters, K. (2012) 'Impact of locus of control expectancy on level of well-being', Review of European Studies. doi: 10.5539/res.v4n2p124.

5. Barling, J., Slater, F. and Kelloway, E. K. (2000) 'Transformational leadership and emotional intelligence: An exploratory study', Leadership \& Organization Development Journal, 21(3), pp. 157-162. doi: 10.1108/01437730010325040.

6. Bennis, W. G. and Thomas, R. J. (2002) 'Crucibles of leadership', Harvard Business Review. doi: 10.1002/pmj.

7. Berson, Y. et al. (2001) 'The relationship between vision strength, leadership style, and context *', Leadership Quarterly. doi: 10.1016/S1048-9843(01)ooo64-9.

8. Blake, R. R. and Mouton, J. S. (1982) 'How to choose a leadership style.', Training and Development Journal. doi: lea.

9. Bolden, R., Gosling, J., Marturano, A. and Dennison, P. et al. (2003) 'A Review of Leadership Theory and Competency
Frameworks':, Centre for Leadership studies. doi: 10.16373/j.cnki.ahr.150049.

10. Bucic, T., Robinson, L. and Ramburuth, P. (2010) 'Effects of leadership style on team learning', Journal of Workplace Learning. doi: 10.1108/13665621011040680.

11. Caliendo, M., Cobb-Clark, D. A. and Uhlendorff, A. (2015) 'Locus of control and job search strategies', Review of Economics and Statistics. doi: 10.1162/REST_a_00459.

12. Carroll, B., Levy, L. and Richmond, D. (2008) 'Leadership as practice: Challenging the competency paradigm', Leadership. doi: 10.1177/1742715008095186.

13. Chen, J. C. and Silverthorne, C. (2005) 'Leadership effectiveness, leadership style and employee readiness', Leadership and Organization Development Journal. doi: 10.1108/01437730510600652.

14. Dahlstrom, T. R. (2013) 'Telecommuting and leadership style', Public Personnel Management. doi: 10.1177/00910260 1349 5731.

15. Dulewicz, V. and Higgs, M. (2005) 'Assessing leadership styles and organisational context', Journal of Managerial Psychology. doi: 10.1108/02683940510579759.

16. Eagly, A. H. and Carli, L. L. (2003) 'The female leadership advantage: An evaluation of the evidence', Leadership Quarterly. doi: 10.1111/j.1550-7408.2011.00593.x.

17. Eagly, A. H., Johannesen-Schmidt, M. C. and Van Engen, M. L. (2003) 'Transformational, Transactional, and Laissez-Faire Leadership Styles: A Meta-Analysis Comparing Women and Men', Psychological Bulletin. doi: 10.1037/0033- 2909.129.4.569.

18. Eagly, A. H. and Johnson, B. T. (1990) 'Gender and Leadership Style: A Meta-Analysis', Psychological Bulletin. doi: 10.1037/ 0033-2909. 108.2.233.

19. Edum-Fotwe, F. T. and McCaffer, R. (2000) 'Developing project management competency: Perspectives from the construction industry', International Journal of Project Management. doi: 10.1016/So263-7863(98)90075-8. 
20. Goleman, D. (2000) 'Leadership that gets Results', Harvard Business Review. doi: 10.1080/14702541208555138.

21. Hollenbeck, G. P., McCall, M. W. and Silzer, R. F. (2006) 'Leadership competency models', Leadership Quarterly. doi: 10.1016/j.leaqua. 2006.04.003.

22. Howell, J. M. and Avolio, B. J. (1993) 'Transformational leadership, transactional leadership, locus of control, and support for innovation: Key predictors of consolidated-business-unit performance.', Journal of Applied Psychology, 78(6), pp. 891-902. doi: 10.1037/0021-9010.78.6.891.

23. Jung, D. I., Chow, C. and Wu, A. (2003) 'The role of transformational leadership in enhancing organizational innovation: Hypotheses and some preliminary findings', Leadership Quarterly. doi: 10.1016/ S1048-9843(03)00050-X.

24. Kerr, S. and Jermier, J. M. (1978) 'Substitutes for leadership: Their meaning and measurement', Organizational Behavior and Human Performance. doi: 10.1016/00305073(78)90023-5.

25. Lyons, J. B. and Schneider, T. R. (2009) 'The effects of leadership style on stress outcomes', Leadership Quarterly. Doi: 10.1016/j. leaqua.2009.06.010.

26. McColl-Kennedy, J. R. and Anderson, R. D. (2002) 'Impact of leadership style and emotions on subordinate performance', Leadership Quarterly. doi: 10.1016/S10 48-9843(02)oo143-1.

27. Mohammad Mosadegh Rad, A. and Hossein Yarmohammadian, M. (2006) 'A study of relationship between managers' leadership style and employees' job satisfaction', Leadership in Health Services. doi: 10.1108/ 13660750610665008.

28. Müller, R. and Turner, J. R. (2007) 'Matching the project manager's leadership style to project type', International Journal of Project Management. doi: 10.1016/j.ijproman. 2006. 04.003.

29. Müller, R. and Turner, R. (2010) 'Leadership competency profiles of successful project managers', International Journal of Project Management. doi: 10.1016/j.ijproman. 2009. 09. 003 .

30. Nanjundeswaraswamy, T. S. and Swamy, D. R. (2014) 'Leadership styles', Advances In Management. doi: 10.1016/B978-184334-658- 6.50003-6.

31. NHS Leadership Academy (2011) Clinical Leadership Competency Framework, NHS Institute for Innovation and Improvement. doi: 10.5042/ijlps.2010.0353.

32. Ogbonna, E. and Harris, L. C. (2000) 'Leadership style, organizational culture and performance: Empirical evidence from UK companies', International Journal of Human Resource Management. doi: 10.1080/ 09585190050075114.

33. Oreg, S. and Berson, Y. (2011) 'Leadership and employees' reactions to change: The role of leaders' personal attributes and transformational leadership style', Personnel Psychology. doi: 10.1111/ j.1744-6570. 2011.0 1221.x.

34. Palmer, B. et al. (2001) 'Emotional intelligence and effective leadership', Leadership \& Organization Development Journal. doi: 10.1108/01437730110380174.

35. Park, D. (1996) 'Gender role, decision style and leadership style', Women in Management Review. doi: 10.1108/o9649429610148737.

36. Rahmasari, L. (2012) 'Pengaruh Kecerdasan Intelektual , Kecerdasan Emosi dan Kecerdasan Spiritual terhadap Kinerja Karyawan', Majalah Ilmiah INFORMATIKA.

37. Rotemberg, J. J. and Saloner, G. (1993) 'Leadership Style and Incentives', Management Science. doi: 10.1287/ mnsc. 39.11.1299.

38. Saeed, T. et al. (2014) 'Leadership styles: Relationship with conflict management styles', International Journal of Conflict Management. doi: 10.1108 /IJCMA-122012-0091.

39. Setiawan, Y. G. (2016) 'Pengaruh Kecerdasan Emosional, Kecerdasan Spiritual, Kecerdasan Intelektual dan Indepedensi pada Kinerja Auditor', e-Jurnal Akuntansi Universitas 
Udayana. doi: 10.1158/1078-0432. CCR13-1517.

40. Solansky, S. T. (2008) 'Leadership style and team processes in self-managed teams', Journal of Leadership and Organizational Studies. doi: 10.1177/1548051808315549.

41. Spector, P. E. (1988) 'Development of the Work Locus of Control Scale', Journal of Occupational Psychology, 61(4), pp. 335-340. doi: 10.1111/j.2044-8325.1988.tboo470.x.

42. Tierney, P., Farmer, S. M. and Graen, G. B. (1999) 'An examination of leadership and employee creativity: The relevance of traits and relationships', Personnel Psychology. doi: 10.1111/j.1744-6570.1999.tboo173.x.

43. Timothy, O. et al. (2011) 'Effects of Leadership Style on Organizational Performance: a Survey of Selected Small Scale Enterprises in Ikosi-Ketu Council Development Area of Lagos State, Nigeria', Australian Journal of Business and Management Research. doi: 10.1038/ncpcardioo726.

44. Tims, M., Bakker, A. B. and Xanthopoulou, D. (2011) 'Do transformational leaders enhance their followers' daily work engagement?', Leadership Quarterly. doi: 10.1016/j.leaqua. 2010.12.011.

45. Trihandini, R. . F. M. (2005) 'Analisis Pengaruh Kecerdasan Intelektual, Kecerdasan Emosi dan Kecerdasan Spiritual terhadap Kinerja Karyawan (Studi Kasus di Hotel Horison Semarang)', Tesis. doi: 10.1016/ j.lfs.2010.05.018.

46. Trihandini, R. A. F. M. (2013) 'Analisis Pengaruh Kecerdasan Intelektual, Kecerdasan Emosi dan Kecerdasan Spiritual terhadap Kinerja Karyawan Program Studi Magister Manajemen Program Pascasarjana Universitas Diponegoro Semarang', Unpiblished Phd Theses.

47. Turner, J. R. and Müller, R. (2005) 'The Project Manager's Leadership Style as a Success Factor on Projects: A Literature Review', Project Management Journal. doi: 10.1177/8756972 80503600206.

48. De Vries, R. E., Bakker-Pieper, A. and Oostenveld, W. (2010) 'Leadership = communication? The relations of leaders' communication styles with leadership styles, knowledge sharing and leadership outcomes', Journal of Business and Psychology. doi: 10.1007/s10869-009-9140-2.

49. Van Vugt, M. et al. (2004) 'Autocratic leadership in social dilemmas: A threat to group stability', Journal of Experimental Social Psychology. doi: 10.1016/Soo22-1031 (03)ooo61-1.

50. Wang, Q., Bowling, N. A. and Eschleman, K. J. (2010) 'A meta-analytic examination of work and general locus of control.', Journal of Applied Psychology, 95(4), pp. 761-768. doi: 10.1037/ao017707.

51. Weinberger, L. A. (2009) 'Emotional intelligence, leadership style, and perceived leadership effectiveness', Advances in Developing Human Resources. doi: 10.1177/ 1523422309360811.

52. Westley, F. and Mintzberg, H. (1989) 'Visionary leadership and strategic management', Strategic Management Journal. doi: 10.1002/smj. 4250100704.

53. Widana, A. C. (2017) 'Pengaruh Kecerdasan Emosional (Eq), Kecerdasan Intelektual (Iq), Kecerdasan Spiritual (Sq), Kecerdasan Sosial, Etika Profesi, Kompetensi Dan Independensi Terhadap Kinerja Auditor', JOM Fekon.

54. Yang, L. R., Huang, C. F. and Wu, K. S. (2011) 'The association among project manager's leadership style, teamwork and project success', International Journal of Project Management. doi: 10.1016/j.ijproman. 2010. 03.006.

55. Zulch, B. (2014) 'Leadership Communication in Project Management', Procedia - Social and Behavioral Sciences. doi: 10.1016/ j.sbspro. 2014. 03.021.

Emotional Intelligence and Leadership Style as Determining Factors of Individual Employee Competencies 


\section{London Journal Press Membership}

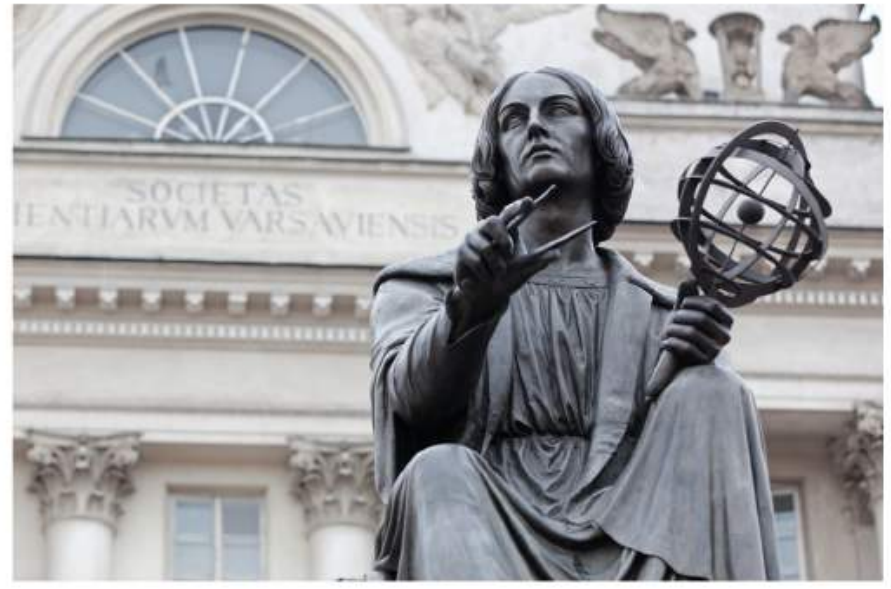

London Journals Press membership is an elite community of scholars, researchers, scientists, professionals and institutions associated with all the major disciplines.

London Journals Press memberships are for individuals, research institutions, and universities. Authors, subscribers, Editorial Board members, Advisory Board members, and organizations are all part of member network.

Read more and apply for membership here:

https://journalspress.com/journals/membership

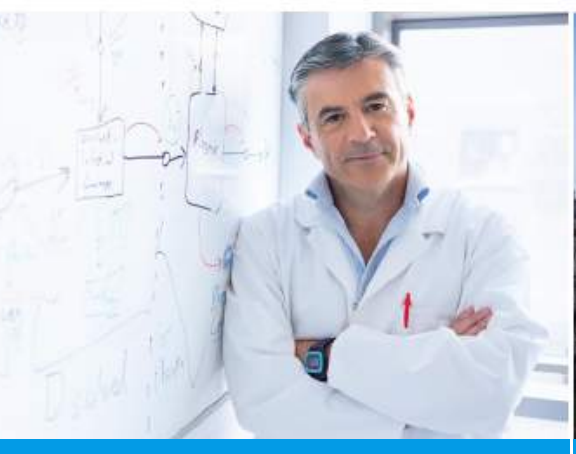

For Authors

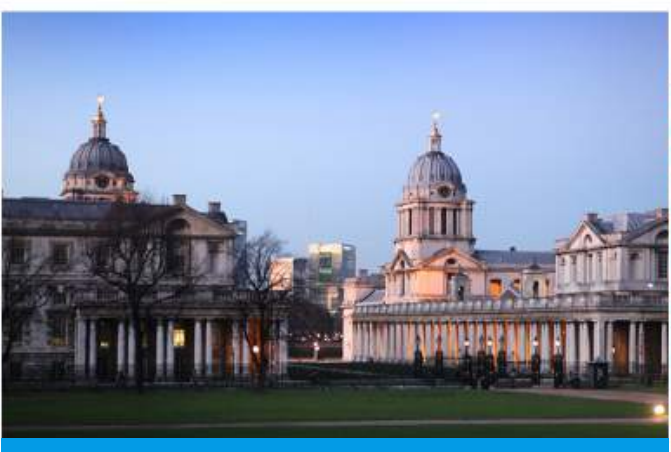

For Institutions

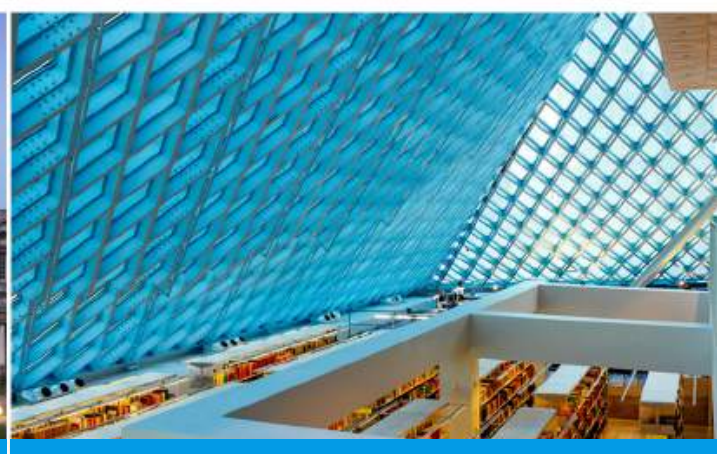

For Subscribers
Author Membership provide access to scientific innovation, next generation tools, access to conferences/seminars

/symposiums/webinars, networking opportunities, and privileged benefits.

Authors may submit research manuscript or paper without being an existing member of LJP. Once a non-member author submits a research paper he/she becomes a part of "Provisional Author Membership".
Society flourish when two institutions come together." Organizations, research institutes, and universities can join LJP Subscription membership or privileged "Fellow Membership" membership facilitating researchers to publish their work with us, become peer reviewers and join us on Advisory Board. 


\section{JOURNAL AVAILABLE IN}

PRINTED VERSION, INTERACTIVE PDFS, EPUBS, EBOOKS, INDEXABLE DOCUMENTS AND THE AUTHOR MANAGED DYNAMIC LIVE WEB PAGE ARTICLES, LATEX, PDFS, RESTRUCTURED TEXT, TEXTILE, HTML, DOCBOOK, MEDIAWIKI MARKUP, TWIKI MARKUP, OPML, EMACS ORG-MODE \& OTHER

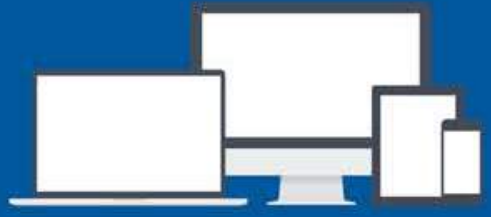

support@journalspress.com www.journalspress.com 